\title{
The Red Sea: A Natural Geodynamic and Metallogenic Laboratory
}

\author{
by Yves Thisse, Pol Guennoc, \\ Georges Pouit and Zohair Nawab
}

\begin{abstract}
As one of the youngest oceanic zones on Earth - an ocean in the making - the Red Sea is of enormous interest in understanding structural and tectonic phenomena related to ocean floor spreading and in reconstructing the history of the global tectonics. In addition, in the last twenty years metalliferous deposits have been discovered in the Red Sea. Their study should lead to a better understanding of processes of metal concentration and to useful guides in the exploration for new deposits, such as those associated with old oceanic formations.
\end{abstract}

\begin{abstract}
Introduction
Separating the Arabian and Nubian plates, the Red Sea is an elongated, narrow depression nearly $2000 \mathrm{~km}$ long and averaging $300 \mathrm{~km}$ in width. It is relatively deep, exceeding $2000 \mathrm{~m}$ in the axial zone and almost closed in the south where only the shallow strait of Bab-el-Mandeb connects it to the Indian Ocean through the Gulf of Aden.
\end{abstract}

Although the history of investigation of the Red Sea goes back to the late 19th century, the mid-1960s mark the true beginning of its scientific exploration, with oceanographic studies increasing both in number and diversity (Table 1). The first major result was the demonstration of the basaltic nature of the axial rift and the conclusion that the Red Sea opened by a process of oceanic accretion (Chase, in Degens and Ross, 1969; Falcon et al., 1970; Coleman, 1974). Of equal importance was the discovery of metalliferous sediments covered by hot brines at the bottom of depressions or deeps usually situated along the rift axis (Degens and Ross, 1969).

The scientific results, together with the potential mining value of certain of the Red Sea deposits, led in 1974 to the creation of the Saudi-Sudanese Red Sea Commission. The SSRSC then hired Preussag (F.R.G.) and BRGM (France) to verify the economic importance of the deposits and to study processes for eventual recovery and treatment of the metalliferous muds, as well as the ecological impact of such development. The mineral reconnaissance work very soon focussed on the Atlantis II Deep - opposite Jeddah - a site $60 \mathrm{~km}^{2}$ in area and $220 \mathrm{~m}$ deep. With nearly 700 core samples, this is now one of the best-explored underwater zones in the world.

\section{An Ocean in the Making}

Morphologically, the Red Sea consists of a narrow continental shelf to the east and west, a wide central depression extending from $15^{\circ} \mathrm{N}$ to the tip of Sinai $\left(28^{\circ} \mathrm{N}\right)$ and contained between the $600 \mathrm{~m}$ and $1500 \mathrm{~m}$ bathymetric contours, and $\mathrm{a}$ narrow, clearly marked axial valley or rift from $15^{\circ}$ to $24^{\circ} \mathrm{N}$ (Fig. 1). The latter is $30 \mathrm{~km}$ wide and up to $2000 \mathrm{~m}$ or more deep, and is characterized by irregular topography and stepped sides, similar to the Mid-Atlantic Rift. The axial zone of the Red Sea has a tholeiitic substratum and was formed by oceanic accretion. Magnetic lineations indicate

Table 1. Major Investigations of Red Sea Deeps

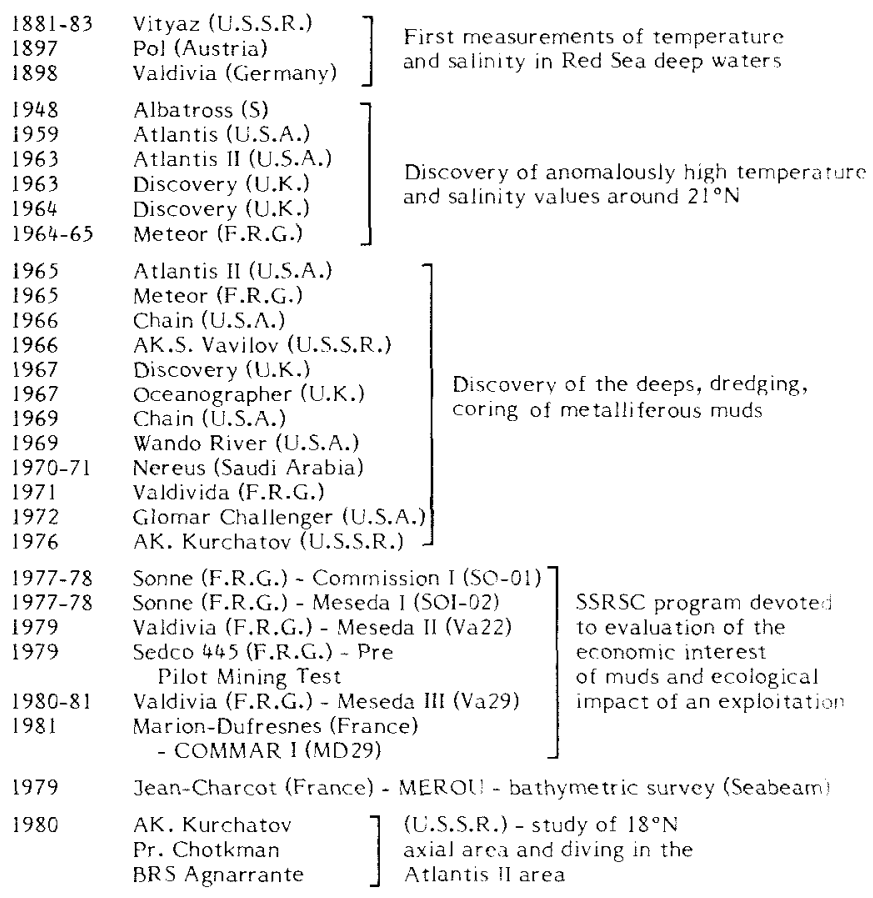


Hackett, J.P. and Bischoff, J.L., 1973. New data on the stratigraphy, extent, and geologic history of the Red Sea geothermal deposits. Economic Geology, v. 68, no. 4, p. 553-564.

Hall, S.A., Andreasen, G.E. and Girdler, R.W., 1977. Total-intensity magnetic anomaly map of the Red Sea and adjacent coastal areas, a description and preliminary interpretation. In: Red Sea Research, 19701975, Saudi Arabia, Directorate General of Mineral Resources, Bulletin no. 22, p. FIF15.

Hartmann, M., 1980. Atlantis II Deep geothermal brine system. Hydrographic situation in 1977 and changes since 1965. Deep Sea Research, v. 27 , no. 2 A, p. $161-171$

izzeldin, A.Y., 1982. On the structure and evolution of the Red Sea based on geophys:cal data from the central and northern parts. Ph.D. Thesis, Strasbourg, 165p.

Länge, J., Bäcker, H. and Karbe, L., 1981. Erzschlamme im Atlantis II Tief-Lagerstätten und Umweltuntersuchung. International Conference on Ocean Mining, Düsseldorf, 1981, p. 91-102.

Le Pichon, X. and Francheteau, F,, 1978. A plate tectonic analysis of the Red Sea-Gulf of Aden area. Tectonophysics, v. 46, no. 34, p. 369-406.

Lowell, J.D. and Genik, G.J., 1972. Sea-floor spreading and structural evolution of the
Southern Red Sea. American Association of Petroleum Geologists Bulletin, v. 56, no. 2, p. 247-259.

Lupton, J.E., Weiss, R.F. and Craig, H., 1977. Mantle helium in the Red Sea brines. Nature, v. 266, no. 5599, p. 244-246.

Manheim, F.T., 1974. Red Sea Geochemistry. In: Whitmarsh, R.B., et al. (eds.), Initial Reports of the Deep Sea Drilling Project, v. 23, U.S. Government Printing Office, $p$. 975-998.

Oudin, E., 1981. Étude minéralogique et géochimique des dépôts sulfurés sous-marins actuels de la ride Est-Pacifique $\left(21^{\circ} \mathrm{N}\right)$. Documents BRGM, v. 25, 24lp.

Oudin, E., 1983. Minéralogie de gisements et indices liés à des zones d'accrétion océaniques actuelles (ride Est-Pacifique et mer Rouge) et fossile (Chypre). Chronique de la recherche minière, v. 470, p. 43-56.

Oudin, E. and Thisse, Y., 1983. Fluides minéralisateurs de haute température dans la mer Rouge. Géochronique, v, 2, p. 5.

Pottorf, R.J. and Barnes, H.L., 1978. The nature of hydrothermal sediments in the Atlantis II Deep of the Red Sea. Geological Society of America, Abstracts with programs, vol. 10, no. 7 , p. 473 .

Pouit, G., Bigot, M., Delfour, J., Mileso, J.-P. and Picot, P., 1982. Les minéralisations actuelles et anciennes: l'exemple de la mer Rouge. Documents du BRGM, no. 52, 90p.

Schoell, M. and Faber, E., 1978. New isotopic evidence for the origin of Red sea brines. Nature, v. 275 , no. 5679 , p. 436-438.

Shanks, W.C., III, and Bischoff, J.L., 1980 Geochemistry, sulfur isotope composition and accumulation rates of Red Sea geothermal deposits. Economic Geology, v. 75, no. 3, p. 445-459.

Thisse, Y., 1982. Sédiments métallifères de la fosse Atlantis II (mer Rouge). Contribution à l'étude de leur contexte morpho-structural et de leurs caractéristiques minéralogiques et géochimiques. Thèse Université Orléans et BRGM, 155p.

Thisse, Y., Oudin, E. and Ramboz, C., 1983. Boiling fluids in the Red Sea metalliferous sediments. Current European Research on Fluid Inclusions, abstract.

Weiss, H.M., Nöltner, T. and Stoffers, P., 1980. The occurrence of ilvaite in metalliferous brine muds from the Red Sea. Neues Jahr buch fïr Mineralogie Abhandlungen, v. 139 , no. 3, p. 239-253.

Zierenberg, R.A. and Shanks, W.C., III, 1983. Mineralogy and geochemistry of epigenetic features in metalliferous sediment, Atlantis II Deep, Red Sea. Economic Geology, v. 78, по. 1 , p. $57-72$.

NEW IUGS PUBLICATION

THE ORDOVICIAN SYSTEM IN SOUTHWESTERN EUROPE

\section{NEW IUGS PUBLICATION}

(France, Spain and Portugal):

\section{Correlation Chart and Explanatory Notes}

by

W. Hammann, M. Robardet and M. Romano

with the collaboration of M.D. Gil, J.C. Gutierrez, P. Herranz, A. Marcos, J. Martin, J.R. Palaez, A. Perez-Estaun, M. Prieto, I. Rabano, M.A. de San Jose, J. Trujols, R. Vegas, L. Vilas, E. Villas and J. Villena.

IUGS Publication 11, 1982, 47 p., one map and one correlation chart. Sponsored by IUGS Subcommission on Ordovician Stratigraphy. $\$ 7.50$ (U.S.).

\section{Available from:}

EPISODES

601 Booth Street

Room 177

Ottawa, Ontario

Canada KIA OE8 or

Maison de la Geologie

77, rue Claude Bernard

75005 Paris

France

THE CAMBRIAN SYSTEM IN THE NEAR AND MIDDLE EAST

Correlation Chart and Explanatory Notes

by

R. Wolfort

IUGS Publication 15, 1983, 70p., one figure and one four-colour correlation chart. Sponsored by IUGS International Subcommission on Cambrian Stratigraphy. \$10.00 (U.S.)

Available from:

EPISODES

601 Booth Street

Room 177

Ottawa, Ontario

Canada KIA OE8 or

Moison de la Geologie

77 , rue Claude Bernard 75005 Paris

France 

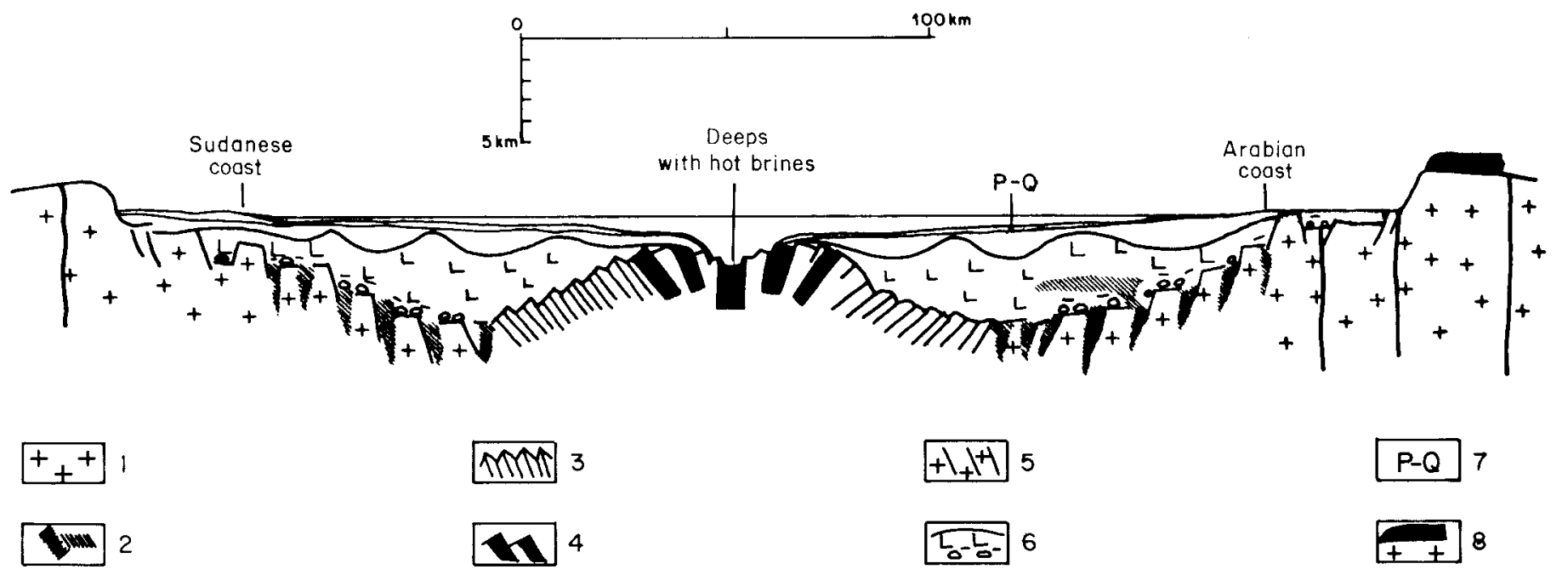

Figure 1: Schematic section of the Red Sea in the area $19^{\circ}$ to $24^{\circ} \mathrm{N}$, after El Tayeb et al (1979), Cochran (1981) and Izzeldin (1982). Basement structures not to scale. 1 -continental crust of the Arabo-Nubian Precambrian basement; 2 - mainly Miocene volcanics; 3 - proto-oceanic crust formed at a very slow rate under unit 6; 4 - Pliocene to Recent oceanic crust; $\mathbf{5}$ - Early Miocene (19-26 Ma) diabase dykes (Blank, 1977); 6 - Middle to Upper Miocene massive salt covered by stratified evaporites; 7 Pliocene to Quaternary sediments; 8 - Miocene to Recent basalt plateaus.

that the spreading occurred between 5 and $6 \mathrm{Ma}$ ago in the southern part and seems to be advancing from the south to the nor th (Drake and Girdler, 1964; Izzeldin, 1982)

The substratum under the other parts of the Red Sea is difficult to study because it is covered by a thick Miocene evaporite series, which extends down $3000 \mathrm{~m}$ or more in places. The top of this formation is marked by a strong seismic reflector similar to the one observed in the Mediterranean. Under the influence of salt tectonics, the evaporites have flowed over the newly formed crust, partly covering it, and, in the north where accretion has still not been effective, it occupies the entire width of the Red Sea.

The Red Sea is thus a geologically recent opening in the Afro-Arabian continent. Following a pre-rifting phase during the Oligocene, the central depression began to form only during the lower Miocene. A long and vigorous debate continues over the nature of the crust in the marginal regions. Is it continental material that has undergone largescale stretching and thinning before opening in the early Pliocene (Lowell and Genik, 1972; Le Pichon and Francheteau, 1978), or does it represent an oceanic crust formed during the Miocene or even earlier (Hall et al., 1977)? The latter alternative is supported by certain magnetic lineations, the thickness of the crust in these regions and the terrestrial volcanism in southern Arabia.

An explanation for many observations was put forward by Cochran (1981) for the Gulf of Aden and later for the Red Sea (1983), based on opening by continental stretching with associated basic intrusions. These models account for the clearly observable magnetic lineations, especially in the southern part of the Red Sea; these apparently correspond to terrestrial intrusions, particularly those of the Arabian Shield (Blank, 1977). Cochran's model also explains the presence of outcrops of Precambrian basement off the coastal areas, such as Zabargad Island (Bonatti et al., 1981,) and similar inliers inferred elsewhere from seismic refraction velocities (Drake and Girdler, 1964). It also accounts for numerous indications of Miocene volcanism and for the existence of intrusions in the Miocene salt-bearing series (Lowell and Genik, 1972).

Indeed the opposing hypothesis of an oceanic crust covering the full width of the Red Sea implies an abrupt rupture of the continental crust which is very unlikely (Lowell and Genik, 1972). There is also the difficulty in attempting to recon- struct the pre-opening period and of covering the continental masses to the south and north (Le Pichon and Francheteau, 1978).

Using aeromagnetic, multitrace seismic reflection and gravimetric data collected by the SSRSC between $18^{\circ}$ and $24^{\circ} \mathrm{N}$, Izzeldin (1982) supports the concept of stretching of the continental crust, combined with basic intrusions. Between 10 and $12 \mathrm{Ma}$ ago this process led to the creation of a "diffuse oceanic" crust formed at a low expansion rate, at least in the area between $17^{\circ}$ and $19^{\circ} \mathrm{N}$. The complete rupture of the continental crust had to occur before true oceanic accretion appeared 5 to $6 \mathrm{Ma}$ ago, accompanied by the gradual spreading out of the Miocene salt cover to outcrops in the axial regions of the oceanic crust.

The long debate is obviously not over yet, for deep drilling through the thick evaporites is still required. Nevertheless there is general agreement that spreading is advancing from south to north, with geomorphological and structural features that correspond to rather advanced stages of opening.

\section{Mineralization - Cretaceous to the Pleistocene}

In addition to the zinc, copper, silver and other deposits of the present axial deeps, a number of older occurrences (Fig. 2) have been found during exploration along the edges of the Red Sea (Pouit et al., 1983).

The Late Cretaceous to Eocene pre-rifting period was characterized by tectonic instability due to regional uplift, by erosion of the cover and by alkaline magmatism. The latter comprises mainly alkaline basalt $f$ lows and annular complexes with nepheline syenites, essexites and carbonatites and trachytes, phonolites, rhyolites and pyroclastics. The lavas are found only in Yemen to the south, while the ring complexes are found in Sudan and Egypt, in places with a NNW alignment similar to that of the future Red Sea rift.

Two kinds of mineral deposits were formed during this period, but only in the northern part of the Red Sea region. First, there are marine phosphates of Upper Cretaceous (Egypt and Saudi Arabia) to Eocene age (Saudi Arabia), but set back from the Red Sea itself. These are likely to be related to special palaeoclimatic conditions which existed from Morocco to Syria, but the morphology of the basin at this pre-rift stage probably provided a trap for the deposits. Secondly, in association with the ring complexes there are rare earths, $U$, 


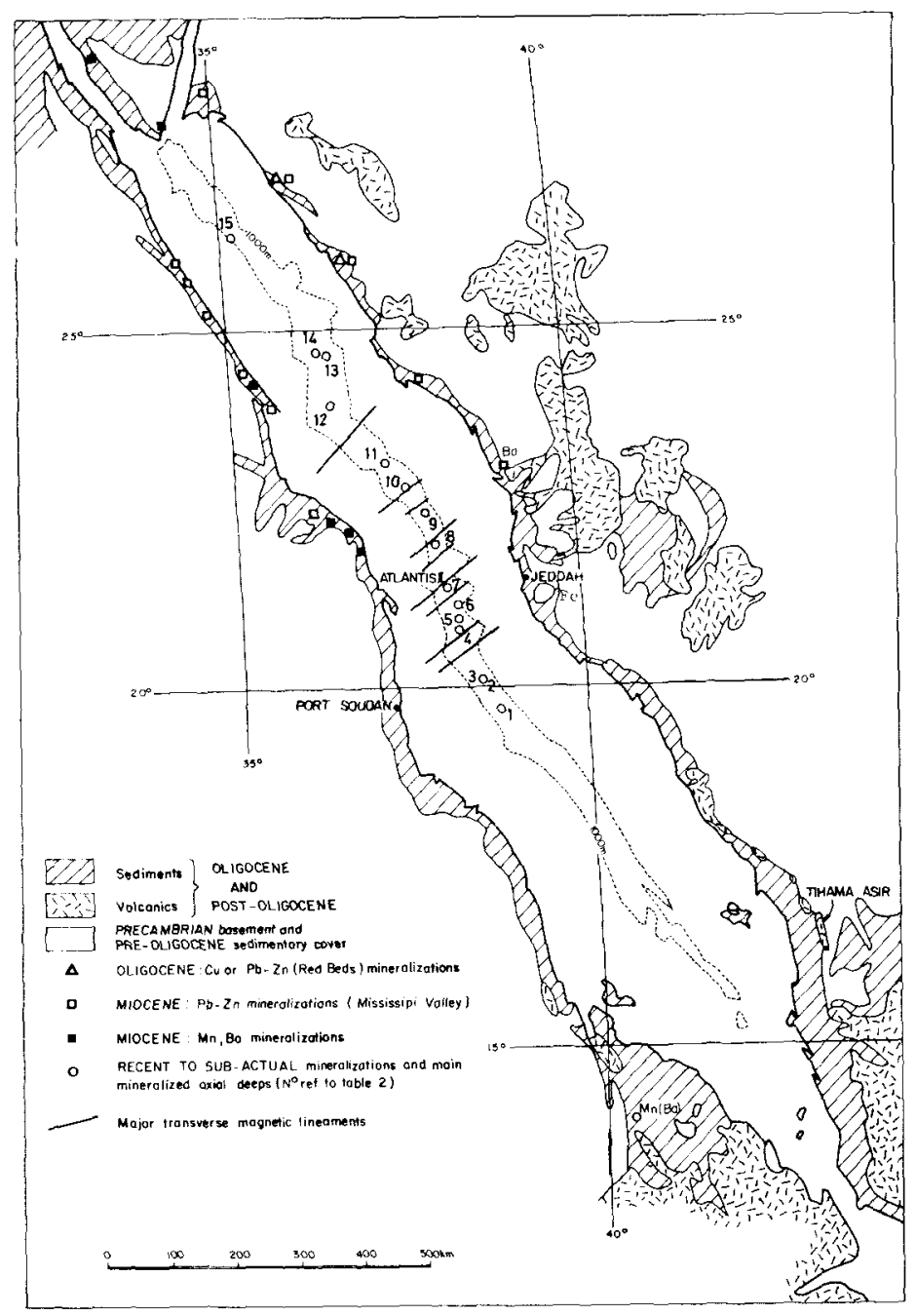

Figure 2: Regional Setting and Tertiary to Recent Mineral Deposits of the Red Sea.

$\mathrm{Ni}, \mathrm{Ta}$ and other related minerals, together with $\mathrm{Al}$ which may one day be of economic interest.

During the Oligocene, the Red Sea began following its own special path of development. This is marked by an absence of marine deposits, by intense erosion with formation of conglomerates (in places very coarse-grained) and other detrital deposits, and by the start of extensive volcanism, especially in Ethiopia and Yemen. Oligocene deposits rest unconformably on the basement rock or in a few places on CretaceousEocene rocks. Horsts and grabens are particularly evident along the Arabian margin and seem clearly controlled by older structures in the basement.

The associated mineralization is of two kinds. First there are red beds with copper or $\mathrm{Pb}-\mathrm{Zn}$ which seem to be mutually exclusive. The metals in stratiform deposits, found especially in northwest Saudi Arabia, impregnate colourless detrital horizons interstratified with red formations. Oolitic iron deposits comprise the second group. Large concentrations ( $50 \mathrm{Mt}$ at $44 \%-50 \% \mathrm{Fe}$ ) are observed in the Wadi Fatima graben east of Jeddah. Oolitic iron occurs at two levels in the Shumargsi Formation (Eocene to the Oligocene) which consists of red detrital deposits, cherts, tuffs and basic lavas.

In the Miocene, the separation between Africa and Arabia became more pronounced and the Red Sea depression was formed. Mineralization was common along both sides of the northern half of the Red Sea, particularly in the earlier reactivated grabens where differentiated sediments such as marls, evaporites and reef deposits are found. Occurrences have been recorded of $\mathrm{Mn}, \mathrm{Ba}$ and/or $\mathrm{Pb}-\mathrm{Zn}$ (with $\mathrm{Ba}, \mathrm{Cu}$ and $\mathrm{Ag}$ ), the latter sometimes dubiously assigned to the "Miscissippi Valley" type.

This Miocene mineralization seems to be penecontemporaneous with the deposition of the host sediments but with a source from deep hydrothermal solutions. Deposits range from concordant to cross-cutting and are localized in certain Miocene reef and conglomeratic facies, strictly controlled by modern tectonics. Found are diffuse impregnations, blobs, peneconcordant pockets and veinlets sometimes (as at $\mathrm{Umm}$ Ghaeig in Egypt) constituting cross-cutting bodies along faults and peneconcordant interdigitations. In all cases there is an apparent direct or indirect structural control. Yet the discordant mineralizations are not primary and certainly cannot be due to later remobilization. A hydrothermalsedimentary origin seems therefore likely.

Several deposits are related to the opening of the southern Red Sea between 5 and $6 \mathrm{Ma}$ ago. These include horizons of black shales drilled by the Glomar Challenger in the postevaporite marine sediments, which are slightly enriched by several hundred ppm of $\mathrm{Cu}$ and $\mathrm{Zn}$ (Manheim, 1974) and concentrations of manganese found in brownish reef limestones. The Mn-Fe (Ba) deposit (Bonatti et al., 1972) of the east edge of the Afars rift, separated from the Red Sea by an outlier of continental crust (the Danakil horst), was formed 200000 years ago on oceanic crust covered by a basal conglomerate composed of volcanic clasts. The deposit is two meters thick with iron at the base and manganese at the top. It has a gangue of opal and barite and extends over several square kilometers, representing several million tonnes of ore.

These deposits and many other shows found in the Afar depression are located at the edge of oolitic reef limestones, and their origin is certainly hydrothermal-sedimentary. Moreover, hydrothermal activity is present throughout the whole region, as shown by numerous hot springs $\left(50^{\circ} \mathrm{C}\right.$ to $100^{\circ} \mathrm{C}+$ ), the hot brines of Lake Giuletti in the Afar depression (comparable to those of the Atlantis II Deep), and by high temperatures and precipitates of massive sulphides (e.g. galena) recorded in drill holes on the shores of Lake Asal, Dibouti.

\section{Recent to Present Day Metalliferous Sediments}

The key to the origin of the older deposits undoubtedly lies in the presence along the rift axis of troughs containing Recent to modern-day metalliferous sediments usually covered by hot brines. The most significant example of these is the Atlantis II Deep.

The first true temperature and salinity anomalies in the deep water of the Red Sea opposite Jeddah were revealed in 1948 by the Swedish ship Albatross. Other measurements taken in this area confirmed these anomalies and led to the discovery of metalliferous sediments at the bottom of depressions along the rift axis. Of the 24 troughs with mineralized sediments and/or hot brines discovered to date (Table 2), only the Atlantis II Deep which is the most heavily mineralized, has been studied in detail (Guennoc and Thisse, 1982).

\section{Atlantis II Deep - Morphology and Structure}

The Atlantis II Deep (Fig. 3) appears at $21^{\circ} \mathrm{N}$ as a $2200 \mathrm{~m}$ deep trough, $14 \mathrm{~km} \times 5 \mathrm{~km}$ in area, trending in the general direction of the axial valley. Its outer contours are limited mostly to the 2000 meter isobath, which corresponds to the top of the hot brines that fill it. Bäcker and Richter (1973) subdivide the deep into four basins joined by thresholds or "passes", which are gaps between blocks of rock emerging from the brines. The largest of these is the Central Sill.

The east and west sides of Atlantic II are bounded by stepped fault scarps (Fig, 3), which recall the morphology of another slow-spreading ridge, that of the Mid-Atlantic. To the south and north, the axial zone has a maximum depth of 1500 
CHARACTERISTICS OF THE BRINES AND METALLIFEROUS SEDIMENTS OF THE MAIN AXIAL DEEPS

from Bäcker and Schoell (1972) and Bignell et al. (1976)

\begin{tabular}{|c|c|c|c|c|c|c|c|c|c|}
\hline NAME & DEPTH & $\begin{array}{l}\text { Thick } \\
\text { in } m\end{array}$ & $\begin{array}{l}\text { BRINE } \\
\text { Ternp. } \\
\text { in }{ }^{\circ} \mathrm{C}\end{array}$ & \multirow{2}{*}{$\mathrm{CI} x$} & \multicolumn{4}{|c|}{$\begin{array}{l}\text { METALLIFEROUS MUDS } \\
\text { Approximate content of }\end{array}$} & $\begin{array}{l}\text { Fig.2 } \\
\text { Ref. }\end{array}$ \\
\hline & & & & & & & & & \\
\hline SIIAKIN & 2850 & $\begin{array}{l}54- \\
74\end{array}$ & 24 & 86 & 10 & 3 & $\begin{array}{r}700- \\
3000\end{array}$ & $70-300$ & 1 \\
\hline VOLCANO & $\begin{array}{l}2050- \\
2400\end{array}$ & \multicolumn{3}{|c|}{ no brines } & \multicolumn{4}{|c|}{ t $r$ a $<$ e 5} & 2 \\
\hline PORT SUDAN & 2830 & 322 & 36.2 & 125 & 5 & 0.3 & 360 & 70 & 3 \\
\hline ERBA & 2396 & 19 & $2 s$ & 86.5 & & $t+$ & ce 5 & & 4 \\
\hline SHAGARA & 2496 & 8 & $\because$ & 113 & 3.5 & 3.0 & 200 & 70 & 5 \\
\hline ALBATROSS & 2133 & 72 & 24.4 & 143 & 5 & 0.3 & 300 & 70 & 6 \\
\hline \multirow{3}{*}{ CHAIN B } & 2072 & 83 & $5 ?$ & 154 & 12 & 35 & 12000 & 200 & ] \\
\hline & 2130 & 140 & 46.5 & 146 & 12 & 35 & 12000 & 200 & \\
\hline & 2165 & 167 & $4: 3$ & 154 & \multicolumn{4}{|c|}{ no metalliferous sediments } & \\
\hline DISCOVERY & 2224 & 209 & 45 & 155 & 10 & 1.3 & 1400 & 100 & 7 \\
\hline VALDIVIA & $\frac{1500-}{1673}$ & 123 & 30 & 145 & 5 & 0.4 & 250 & 80 & \\
\hline ATLANTISII & 2200 & 200 & $\begin{array}{l}50- \\
64\end{array}$ & $\begin{array}{l}92- \\
188\end{array}$ & 28 & 5 & 34000 & 13000 & ] \\
\hline HATIBA & 2300 & & & & 20 & 0.6 & 850 & 2500 & 8 \\
\hline HADARBA & 2200 & & & & 3.5 & 0.6 & 300 & 70 & 9 \\
\hline THETIS & 1970 & no & obri & & 23 & 9 & 4200 & 750 & 10 \\
\hline $\begin{array}{l}\text { YEREUS } \\
\text { (E Rasin) }\end{array}$ & 2458 & 39 & 30 & 165 & 10 & 2 & 1500 & 150 & 11 \\
\hline VEMA & 1611 & по & $0 \mathrm{~s} \mathrm{ri}$ & & 5 & 0.3 & 250 & 70 & 12 \\
\hline GYPSLM & 1196 & no & bri & & 20 & 0.3 & 900 & 200 & 13 \\
\hline KEBRIT & 1573 & 107 & 23 & 153 & 3 & 0.3 & 250 & 70 & 14 \\
\hline $\begin{array}{l}\text { OCEANO- } \\
\text { GRAPHER }\end{array}$ & 1528 & $>100$ & $?$ & 160 & 1.11 & 0.4 & 87 & 24 & 15 \\
\hline
\end{tabular}

meters and a low relief. Here the oceanic crust and the central channel disappear under several hundred meters of evaporites and marls for a distance of about $40 \mathrm{~km}$. Beyond this new rift sections reappear with basaltic crust rock and mineralized troughs.

The deep is marked by a number of transverse fractures (Bäcker, 1973; Bäcker et al., 1975; Bignell et al., 1976). Between $20^{\circ}$ and $21^{\circ} 30^{\circ} \mathrm{N}$, three such discontinuities have been discovered, extending nearly to the coastline (Garson and Krs, 1976) and even to land. The accretion axis at the centre of the positive axial anomaly is, in some instances, offset by these faults. This situation, together with magnetic and gravimetric data, indicates clearly that these are transform faults (El Tayeb et al., 1979; Izzeldin, 1982).

\section{Hot Brines and Mineralized Sediments}

The importance of the Atlantis II Deep comes from the existence of a double layer of brines nearly $200 \mathrm{~m}$ thick covering the sediments and screening them from the waters of the Red Sea. It was these brines that led to the discovery of the underlying mineral deposits.

The lower brine (Fig. 3) is nearly $150 \mathrm{~m}$ thick with a temperature approaching $65^{\circ} \mathrm{C}$ in 1983 , high salinity (33\% $\mathrm{NaCl}$ equivalent) and a slightly acidic $\mathrm{pH}(5.6)$. This brine is lacking in oxygen, and relative to normal Red Sea water it is rich in $\mathrm{Na}, \mathrm{Cl}$ and $\mathrm{Ca}$, and low in $\mathrm{Mg}$ and $\mathrm{SO}^{4}$, with metal concentrations as high as a thousand times that of sea water. Such properties characterize this brine as hydrothermal and comparable to the fluids from the hydrothermal vents of the East Pacific Rise. There is a transition in less than a meter to the $30 \mathrm{~m}$-thick upper brine, which has a composition intermediate between that of the lower brine and sea water.

Measurements taken over the last twenty years in the lower brine have shown that its temperature - and that of the geothermal system - has risen from $50^{\circ} \mathrm{C}$ in 1965 . The main thermal discharge zone is located in a sector several square kilometers in area in the centre of the SW basin (Brewer et al., 1971; Hartmann, 1980).
The metalliferous sediments beneath the brines, which were cored first in 1965, are 10-15 $\mathrm{m}$ thick and represent about $100 \mathrm{Mt}$ (million metric tons) in dry weight. Among other metals these sediments contain $3.5 \mathrm{Mt}$ of zinc, $0.5 \mathrm{Mt}$ of copper and $9000 \mathrm{t}$ of silver (Länge et al., 1981), comparable to a sulphide deposit of above average size. As shown in Figure 3, the sediments comprise five lithologic units (Bäcker and Richter, 1973), characterized by a diversity of colours associated with fine bedding. They are virtually saturated (nearly $85 \%$ weight) by saline water with physico-chemical parameters similar to those of the lower brine. The solid fraction has a very small range in grain-size, with about $65 \%$ of the material less than or equal to two microns (Fletcher and Mustafa, 1980).

The basal unit is a biomechanical zone dominated by marls and contains several horizons of iron oxides and pyrite. This zone rests on the basalts and has been dated at 25000 B.P. at its base ( $\mathrm{C}^{14}$ on microfossil tests) and 11000 B.P. at the top (Pleistocene-Holocene transition: Shanks and Bischoff, 1980).

Above the basal zone are two sulphide zones each averaging $2 \mathrm{~m}$ in thickness. These have iron, copper and zinc sulphides associated with clays of the montmorillonite type and sometimes with anhydrite horizons. Between these two zones is an oxidized unit, 5-6 $\mathrm{m}$ thick, of iron and/or manganese oxyhydroxides and argillaceous silicates. At the top of these muds is a delicate semi-liquid zone that can only be sampled as one unit. It is $2-3 \mathrm{~m}$ thick and consists of ferriferous nontronite associated with partially crystalline iron sulphides and oxyhydroxides. These sediments may be forming as rapidly as one meter in several thousand years (Bischoff, in Degens and Ross, 1969; Bäcker and Richter, 1973; Hackett and Bischoff, 1973; Bäcker, 1973; Bignell et al., 1976; Bignell, 1978).

The SW portion of the Atlantis II Deep is somewhat different, with many epigenetic characteristics resulting from recent upwellings of mineralizing fluids (Bäcker and Richter, 1973; Zjerenberg and Shanks, 1983). These features include resedimentation structures, breccias and numerous fine veinlets filled with anhydrite (with crystals to $1 \mathrm{~cm}$ ) and associated with talc and some sulphides. Among the latter are pyrrhotite, chalcopyrite and chalcopyrrhotite $\left(\mathrm{CuFe}_{2} \mathrm{~S}_{3}\right)$. This combination indicates high-temperature circulation (Pottorf and Barnes, 1978; Weiss et al., 1980; Thisse, 1982; Oudin, 1983) and is comparable to that described from high-temperature $\left(350^{\circ} \mathrm{C}\right)$ chimneys of the East Pacific Rise (Oudin, 1981; 1983). The host sediment is locally metamorphosed, as

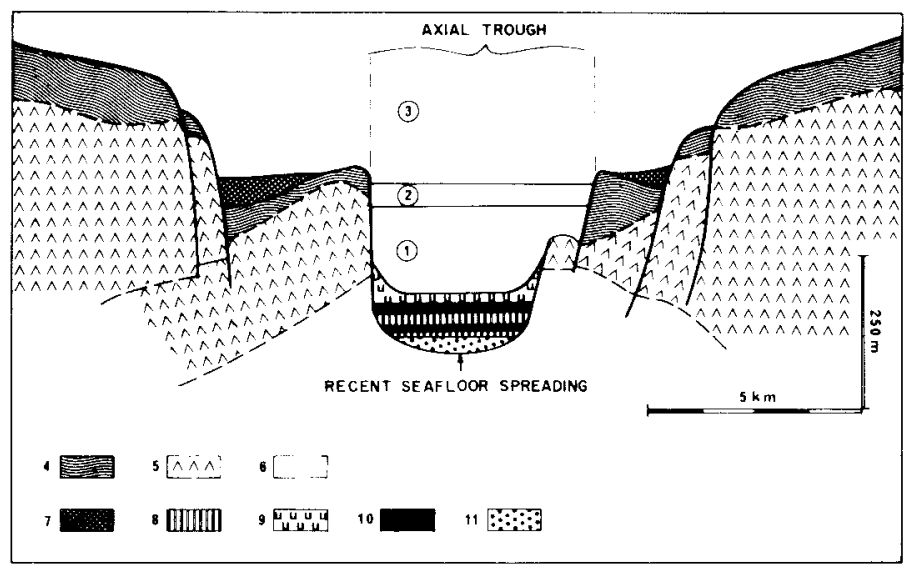

Figure 3: Schematic $E-W$ section through the southern Atlantis II Deep (modified from Bäcker, 1973 and Bignell, 1978). 1 -lower brine; 2 - upper brine; 3 -Red Sea water; 4 Pliocene to Quaternary marls; 5 - Miocene evaporites; 6 oceanic basement; 7 - Fe-Mn oxides; 8 - oxide zone; 9 amorphous silicate zone; 10 -sulphide zones; 11 -biogenicdetrital marls. 
indicated by the presence of magnetite, amphibole of the actinolite type and an Fe-Mn skarn silicate ilvaite (Weiss et al., 1980; Oudin, 1983).

Studies of the fluid inclusions in the anhydrite along the sides of these secondary veinlets were recently undertaken at BRGM on material provided by the SSRSC. We have found two populations of inclusions characterizing the hydrothermal fluids. The first yields a temperature of about $340^{\circ} \mathrm{C}$ for a salinity equivalent to $22 \% \mathrm{NaCl}$, while the second and later group (in places found in halite crystals) indicates temperatures of $400^{\circ} \mathrm{C}$ with a salinity equivalent to $33 \% \mathrm{NaCl}$. At the location sampled, the initial fluid appears to have been boiling, possibly as a result of decompression during fracturing of the pre-existing sediments due to volcanic-tectonic activity periodically affecting these deeps. The boiling would have modified the physico-chemical characteristics of the fluid and induced the precipitation of many elements, especially metals (Thisse et al., 1983).

\section{Origin and Development of the Brines}

The Red Sea brines were first interpreted as coastal evaporite deposits flowing as dense brines to the sea floor, or as the result of leaching of submarine salt-bearing outcrops. Brewer et al. (in Degens and Ross, 1969) rejected these hypotheses and advocated a connate origin for the supersaline water, recirculated by geothermal phenomena. On the basis of isotopic data, Craig (in Degens and Ross, 1969) argued for a correspondence between the brines and the water in the southern part of the Red Sea; however, the long distance implied gives this model little credibility.

Bäcker (1973) and Manheim (1974) were the first to propose a lateral convective flow by which Red Sea water infiltrates and descends into the sides of the rift, heats up as it approaches the ascending magma, dissolves salts and metals and finally rises by ordinary convection to deposit some of its dissolved elements on the sea floor. This mechanism has received much direct and indirect support, particularly through the study of accretion zones and recent discoveries of hydrothermal activity in the eastern Pacific.

The following sequence is now believed to apply to the metalliferous deposits in the Atlantis II Deep. The hydrothermal fluid could be fossil water from the Red Sea, as the isotopic data of Schoell and Faber (1978) indicates an age of 5000 B.P. This fluid is either set in motion by tectonic phenomena related to oceanic expansion, or it percolates very slowly and steadily through the fractures associated with the rift. The salinity of water is due to leaching of the anhydrite and halite which cover most of the floor of the Red Sea.

The heating of this water to several hundred degrees, due to the presence of magma not far below the axial zone results in a number of changes confirmed by laboratory experiments. These changes include lowering of magnesium and sulphate content, acidification and, especially, metal enrichment by leaching of newly formed basalts. Sulphur isotope measurements (Shanks and Bischoff, 1980) indicate additions to these fluids from great depths in the crust and possibly also direct additions from the mantle. Evidence of the latter is provided by helium isotope ratios which show an excess of $\mathrm{He}^{3}$, a typical mantle marker (Lupton et al., 1977) also found systematically at active hydrothermal locations in the Pacific, where they serve as a guide to exploration. In addition to these deep sources, there may also be a leaching of carlier sediments like those found by the Glomar Challenger (Manheim, 1974) - shale horizons interstratified with or overlying the evaporites and bearing rather high contents of metals such as $\mathrm{Zn}$, Mo and $V$.

The hot, concentrated fluids rise along fractures by simple convection to emerge in the bottom of the trough where abrupt changes in physico-chemical conditions (especially the drop in temperature) cause the precipitation of a number of metals. The reducing conditions and the absence of oxyger in this environment favour the formation and preservation of sulphide.

This is the same mechanism as conceived for the actue hydrothermal vents of the East Pacific Rise. However the comparison does not extend beyond the similarities in ten!peratures and mineralogy. The growth of hydrothermal vents in the Red Sea is inhibited by the mass of sediments trapped in the trough, while in the East Pacific they can develop freely at the basalt-seawater interface. The difference in evolution of hydrothermal indicators is thus due to contrasts in the morphological and tectonic environments of these two oceanic accretion zones: the Red Sea is characterized by an early stage of slow opening with deep bathymetry, while the East Pacific Rise is a subject to more rapid and mature spreading.

\section{Comparison with Fossil Deposits Elsewhere}

There are many analogies between the modern deposits of the Red Sea and major $\mathrm{Pb}-\mathrm{Zn}-\mathrm{Cu}-\mathrm{Ag}-\mathrm{Ba}$ deposits elsewhere, especially those found in rifts or abortive grabens of the Proterozoic, such as McArthur River, Mt. Isa and Pegmont in Australia, the Sullivan in British Columbia, and Gamsberg in South Africa. The similarities include the association with ferriferous (banded iron) formations and sulphides with vertical and lateral zoning, lateral changes to $\mathrm{Mn}$, and the existence of siliceous deposits capping the sulphides. In common also are many other aspects typical of exhalative deposits, such as talc deposits, chlorite sometimes altered to cordierite and horizons rich in anorthite. In addition brines typically deposit metals in the deepest parts of their basins.

However, not all aspects of the Red Sea deposits are matched elsewhere, for two main reasons arising from their basically hydrothermal and sedimentary nature. First, the composition and the nature of the hydrothermal solutions and deposition processes vary from one trough to another in the Red Sea, as they do in fossil mineral deposits elsewhere. Second, hydrothermal deposits can form in various geological and structural environments, as shown particularly well by DSDP Leg $X I$ drilling in the marine Cretaceous of the North Atlantic. Thus, just as there is no one model for veins in a single environment, deposits of the Red Sea type, although of sedimentary origin, vary widely from one geological environment to another because of their basically hydrothermal nature.

\section{Comparison with Old Rifts}

There are also similarities between the Red Sea and other rift-based deposits in terms of evolution and geodynamic setting. The most typical examples were formed during the opening of the North Atlantic and of Tethys in the PermoTriassic and Lower Jurassic and during the opening of the South Atlantic in the Cretaceous. In both cases, (e.g. in Morocco, the Benue Trough and Angola) a succession of mineral deposits associated with hyperalkaline carbonatite complexes was followed by $\mathrm{Cu}, \mathrm{Pb}, \mathrm{Zn}, \mathrm{Mn}$ and $\mathrm{Ba}$ mineralizations of the Red Bed and/or Mississippi Valley type. These deposits occur in adjacent basins in "herringbone" fashion along the rifts. Finally, oolitic iron deposits are also often observed in old rifts such as the Proterozoic Labrador Trough and the Benue deep in Nigeria.

\section{Summary}

Study of the mineral associations in secondary veinlets and of the metamorphism of the host sediment has demonstrated the circulation of very hot $\left(350^{\circ}\right)$ saline fluids in the metalliferous sediments of the Atlantis II Deep. For the first time, microthermometric studies on fluid inclusions in sulphates have made it possible to characterize the temperature and salinity variations in these ascending mineralizing fluids.

There are remarkable similarities between the parageneses observed in the Red Sea veinlets and those in the high- 
temperature chimneys of the East Pacific Rise, as well as in their formation temperatures. The different maturity levels of these two accretion zones can explain the specific differences in their hydrothermal deposits.

Mineralization associated with the oceanic ridges and ancient rifts provide most of the basis for comparison with fossil deposits. The Red Sea is of special interest and importance because of its economic significance and the variety of types present at different evolutionary stages of the rift. A close relation has now been demonstrated between geodynamic evolution and the development of the mineralization. The existence of similar mineral variations in older deposits may thus provide a key to their geodynamic setting.

Finally, the studies on the Tertiary mineral deposits along the Red Sea margin have led to a better understanding of the

\section{ABOUT THE AUTHORS:}

Yves Thisse joined the Marine Geology Department of BRGM (B.P. 6009,45060 Orléans Cedex, France) in 1982, after completing his thesis at University of Orléans, on the metalliferous oozes of the Atlantis II Deep. His work on the Red Sea metalliferous deposits continues in collaboration with Elisabeth Oudin.

Pol Guennoc has been with the Marine Geology Department of BRGM since 1978 and is in charge its Centre Océanologique de Bretagne at Brest. His main fields of activity are in submarine geology and the study of recent and ancient hydrothermal deposits. basic characteristics of certain deposits whose origin is still very much a matter of debate. These include red beds, oolitic iron ores and especially deposits of the Mississippi Valley type.

\section{Acknowledgements}

The authors wish to thank the officials of the Saudi-Sudanese Red Sea Joint Commission. With their assistance, BRGM was able to conduct scientific studies on six core samples taken from the Atlantis II Deep. The first results of this work, together with the re-examination of earlier studies, have already provided a fuller understanding of the process of formation of mineral deposits associated with the Red Sea rift.

A mining geologist specializing in mineral deposits, Georges Pouit has worked and studied in Africa, Europe and North America. He is now on the staff of the BRGM Mineral Deposits Department at Orléans. His interests include volcanic-sedimentary ore deposits, in the Red Sea and elsewhere.

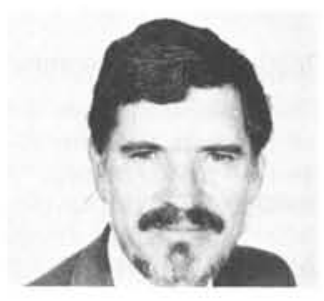

Zohair A. Nawab is the Deputy Secretary-General of the SSRC (Box 5886, Jeddah, Saudi Arabia) and a member of the Saudi Arabian National Committee for Marine Sciences. After studying at Riyadh University and at Dhahran, Saudi Arabia, Dr. Nawab obtained his Ph.D. in geology from the University of Western

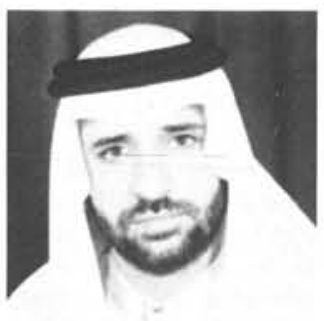
Ontario in 1978.

\section{References}

Bäcker, H., 1973. Rezente hydrothermalsedimentäre Lagerstättenbildung. Erzmetall, v. 26, no. 11, p. 544-555.

Bäker, H., Lange, K. and Richter, H., 1975. Morphology of the Red Sea central graben between Subair Islands and Abul Kizaan. Geologisches Jahrbuch, D. 13, p. 79-123.

Bäker, H. and Richter, H., 1973. Die rezente hydrothermal-sedimentäre Lägerstätte Atlantic-II-Tief im Roten Meer. Geologisches Rundschau, v. 62, no. 3, p. 697-740.

Bignell, R.D., 1978. Genesis of the Red Sea: Metalliferous sediments. Marine Mining, v. 1, no. 3, p. 209-235.

Bignell, R.D., Cronan, D.S. and Tooms, J.S., 1976. Red Sea metalliferous brine precipitates. Geological Association of Canada, Special Paper 14, p. 147-179.

Blank, H.R., Jr., 1977. Aeromagnetic and geologic study of tertiary dykes and related structures on the Arabian margin of the Red Sea. In: Red Sea Research, 1970-1975, DGMR Bulletin No. 22, p. G1-G18.

Bonatti, E., Fisher, D.E., Joensuu, O., Rydell, H.S. and Beyth, M., 1972. Iron-manganesebarium deposit from the nor thern Afar rift (Ethiopia). Economic Geology, v. 67, no. 6, p. $717-730$.

Bonatti, E., Hamlyn, P. and Ottonello, G., 1981. Upper mantle beneath a young oceanic rift; peridotites from the island of Zabargad (Red Sea). Geology, v. 9, no. 10, p. 474-479.
Brewer, P.G., Wilson, T.R.S, Murray, J.W. Munns, R.G. and Densmore, C.D., 1971. Hydrographic observations on the Red Sea brines indicate a marked increase in temperature. Nature, v. 231, no. 5297, p. 37 38.

Cochran, J.R., 1981. The Red Sea: implications for the early development of Atlantictype continental margins. EOS, v. 62, no. 17 , p. 407.

Cochran, J.R., 1983. A model for development of Red Sea. American Association of Petroleum Geologists Bulletin, v. 67, no. 1, p. 41-69.

Coleman, R.G., 1974. Geologic background of the Red Sea. In: Whitmarsh, R.B., Weser, O.E., Ross, D.A. et al. (eds.), Initial Reports of the D.S.D.P., v. 23, p. 813-819, U.S. Geology Survey, Menlo Park, CA, U.S.A.

Degens, E.T. and Ross, D.A., 1969. Hot Brines and Recent Heavy Metal Deposits in the Red Sea, a Geochemical and Geophysical Account. Springer Verlag, New York.

Drake, C.L. and Girdler, R.W., 1964. A geophysical study of the Red Sea. Geophysical Journal of the Royal Astronomical Society, v. 8 , p. 473-495.

E1 Tayeb, M., Izzeldin, Y., Horn, R. and Tixeront, M., 1979. Les données géophysiques de la mer Rouge centrale (entre $18^{\circ}$ et $24^{\circ} \mathrm{N}$ ): leur traitement par la technique SIGMA. In: Scolari, G. (ed.), Ressources Minérales Sous-
Marines, Colloque GERMINAL, 23-27 October 1978, Documents du BRGM, no. 7, p. 367-379.

Falcon, N.L., Gass, I.G., Girdler, R.W. and Laughton, A.S., 1970. A discussion on the structure and evolution of the Red Sea and the nature of the Red Sea, Gulf of Aden and Ethiopia rift junction. Philosophical Transactions of the Royal Society of London, A 267 , no. $1181,417 \mathrm{p}$.

Fletcher, A.W. and Musta Fa, Z., 1980. Progress on the exploitation of metalliferous sediments of the Red Sea. Proceedings of Conference on National and International Management of Mineral Resources, May, 1980, Institution of Mining and Metallurgy, London, 16p.

Garson, M.S, and Krs, M., 1976. Geophysical and geological evidence of the relationship of Red Sea transverse tectonics to ancient fractures. Geological Society of America Bulletin, v. 87, no. 2, p. 169-181.

Girdler, R.W. and Styles, P., 1982. Comments on "the Gulf of Aden: Structure and evolution of a young ocean basin and continental margin" by J.R. Cochran. Journal of Geophysical Research, v. 87, no. B8, p. 67616763.

Guennoc, P. and Thisse, Y., 1982. Genèse de l'ouverture de la mer Rouge et des minéralisations des fosses axiales. Synthèse bibliographique. Documents du BRGM, no. 51, $112 \mathrm{p}$. 